Review

\title{
Good-Practice Non-Radioactive Assays of Inorganic Pyrophosphatase Activities
}

\author{
Alexander A. Baykov ${ }^{1, *}$, Viktor A. Anashkin ${ }^{1}$ and Anssi M. Malinen ${ }^{2, *}$ \\ 1 Belozersky Institute of Physico-Chemical Biology, Lomonosov Moscow State University, \\ 119899 Moscow, Russia; victor_anashkin@belozersky.msu.ru \\ 2 Department of Life Technologies, University of Turku, FIN-20014 Turku, Finland \\ * Correspondence: baykov@belozersky.msu.ru (A.A.B.); ansmal@utu.fi (A.M.M.)
}

Citation: Baykov, A.A.; Anashkin, V.A.; Malinen, A.M. Good-Practice Non-Radioactive Assays of Inorganic Pyrophosphatase Activities. Molecules 2021, 26, 2356. https://

doi.org/10.3390/molecules26082356

Academic Editor: Marko Goliĉnik

Received: 6 April 2021

Accepted: 16 April 2021

Published: 18 April 2021

Publisher's Note: MDPI stays neutral with regard to jurisdictional claims in published maps and institutional affiliations.

Copyright: (c) 2021 by the authors. Licensee MDPI, Basel, Switzerland. This article is an open access article distributed under the terms and conditions of the Creative Commons Attribution (CC BY) license (https:// creativecommons.org/licenses/by/ $4.0 /)$.
Abstract: Inorganic pyrophosphatase (PPase) is a ubiquitous enzyme that converts pyrophosphate $\left(\mathrm{PP}_{\mathrm{i}}\right)$ to phosphate and, in this way, controls numerous biosynthetic reactions that produce $\mathrm{PP}_{\mathrm{i}}$ as a byproduct. PPase activity is generally assayed by measuring the product of the hydrolysis reaction, phosphate. This reaction is reversible, allowing $\mathrm{PP}_{\mathrm{i}}$ synthesis measurements and making PPase an excellent model enzyme for the study of phosphoanhydride bond formation. Here we summarize our long-time experience in measuring PPase activity and overview three types of the assay that are found most useful for (a) low-substrate continuous monitoring of $\mathrm{PP}_{\mathrm{i}}$ hydrolysis, (b) continuous and fixed-time measurements of $\mathrm{PP}_{\mathrm{i}}$ synthesis, and (c) high-throughput procedure for screening purposes. The assays are based on the color reactions between phosphomolybdic acid and triphenylmethane dyes or use a coupled ATP sulfurylase/luciferase enzyme assay. We also provide procedures to estimate initial velocity from the product formation curve and calculate the assay medium's composition, whose components are involved in multiple equilibria.

Keywords: pyrophosphate assay; phosphate assay; malachite green; methyl green; luciferase; ATP sulfurylase; initial velocity; pyrophosphate complexes

\section{Introduction}

Inorganic pyrophosphatase (inorganic diphosphatase; EC 3.6.1.1; PPase) is a constitutive, highly specific enzyme that converts pyrophosphate $\left(\mathrm{PP}_{\mathrm{i}}\right)$, a byproduct and regulator of numerous biosynthetic reactions [1], into a metabolizable phosphate. Ubiquitous soluble PPases dissipate $\mathrm{PP}_{\mathrm{i}}$ energy as heat, whereas less common membrane-bound PPases use the energy to transport $\mathrm{H}^{+}$or $\mathrm{Na}^{+}$across lipid membranes [2,3]. Both PPase types can also catalyze the reverse reaction of $\mathrm{PP}_{\mathrm{i}}$ synthesis from $\mathrm{P}_{\mathrm{i}}$, and this activity of membrane-bound PPases is also considered physiologically important [4,5]. Soluble PPases are additionally divided into two nonhomologous families-family I, known for nearly a hundred years and found in all kingdoms of life, and family II found in 1998 in prokaryotes [6,7]. Several nonspecific phosphatases also exhibit PPase-like activity [8-10].

Although the primary structures of the three groups of specific PPases are completely different, their mechanisms and active sites reveal close similarity, making these enzymes remarkable examples of convergent evolution. All PPases are $\mathrm{Mg}^{2+}$-dependent enzymes, but family II PPases additionally require a transition metal ion $\left(\mathrm{Mn}^{2+}\right.$ or $\left.\mathrm{Co}^{2+}\right)$ for maximal activity [11]. In total, three to four metal ions per active site are required for $\mathrm{PP}_{\mathrm{i}}$ conversion [7]. These metal ions, coordinated by numerous protein carboxylates and substrate phosphates, play key roles in catalysis. $\mathrm{PP}_{\mathrm{i}}$ hydrolysis involves a direct attack of an activated water molecule on a phosphorus atom and a stepwise release of two phosphate molecules. The value of $k_{\text {cat }}$ for soluble PPases reaches $10^{4} \mathrm{~s}^{-1}$ for $\mathrm{PP}_{\mathrm{i}}$ hydrolysis and $10^{2} \mathrm{~s}^{-1}$ for $\mathrm{PP}_{\mathrm{i}}$ synthesis $[3,4,11] . K_{\mathrm{m}}$ values for most PPases with $\mathrm{PP}_{\mathrm{i}}$ as substrate lie in the micromolar range. 
PPase is generally assayed by measuring phosphate, the product of $\mathrm{PP}_{\mathrm{i}}$ hydrolysis. Depending on the task, PPase activity is assayed at sub- $K_{m} P P_{i}$ concentrations (in mechanistic studies) or a saturating $\mathrm{PP}_{\mathrm{i}}$ concentration (in high-throughput screening procedures). The former assay is more demanding concerning sensitivity because of the low $K_{\mathrm{m}}$ value, especially with family I and membrane PPases. Sensitivity is also the limiting factor in $\mathrm{PP}_{\mathrm{i}}$ synthesis studies because the equilibrium $\mathrm{PP}_{\mathrm{i}} \leftrightarrows 2 \mathrm{P}_{\mathrm{i}}$ is largely shifted to the right. Here, we summarize our experience in sensitive PPase activity measurements in both directions and present protocols suitable for high-throughput screening and mechanistic studies.

\section{Continuous Low-Substrate Assay of $\mathbf{P P}_{\mathbf{i}}$-Hydrolyzing Activity}

The low value of the Michaelis constant of PPases makes it necessary to use highly sensitive assays in kinetic studies conducted at sub- $K_{\mathrm{m}}$ substrate concentrations. The assay currently used in our labs combines two approaches to achieve high sensitivity: first, it measures the formation of the intensively colored complex of 12-molibdophosphoric acid with a triphenylmethane dye, methyl green, and, second, it is continuous. The PPase reaction mixture and two-color reagents are continuously pumped off by a peristaltic pump and mixed, and the absorbance of the resulting solution is measured at 620 or $660 \mathrm{~nm}$ in a flow photometer. Even though the background absorbance is relatively high, it is automatically subtracted in this continuous assay mode, allowing the precise recording of much smaller changes in absorbance ( $P_{i}$ concentration) compared to a fixed-time assay. The principal advantage of the methyl green dye in this application is its low tendency to deposit on the optical cuvette [12].

The phosphate analyzer consists of three main parts: a four-channel peristaltic pump, flow photometer, and paper recorder (Figure 1A). Alternatively, the photometer's output can be directed to a computer, which calculates initial velocity from the absorbance timecourse. However, we found that the manual procedure, using paper recordings, is less sensitive to signal fluctuations and provides more accurate data. We have used a fourchannel Gilson Minipuls pump equipped with Tygon tubings. Three pump channels are used to deliver a sample, acid/molybdate, and dye/Triton X-305 solutions. Their initial mixing occurs in tubing T-joints and is completed in a mixing device consisting of a glass tube of $1.3 \mathrm{~mm}$ inner diameter with $12-15$ bubbles of $3.5 \mathrm{~mm}$ inner diameter. The fourth pump channel eliminates any air bubbles from the final mixed solution before it is directed to the flow photometer. To prevent excessive air from entering the flow system, the pump is stopped when the sample inlet tubing is transferred between the samples and water. To ensure that the color reaction proceeds to completion, the time intervals between the two mixing events and between the second mixing event and entry to the photometer cuvette should be adjusted to 12 and $32 \mathrm{~s}$, respectively, by using connecting tubings of appropriate diameter and length. The small nonlinearity of the calibration plot at low phosphate content is eliminated by adding a small amount of phosphate to the stock acid/molybdate solution. We have been using ISCO UA-5 and 229 flow photometers. These instruments are no longer produced but can be replaced by any flow photometer operating at $620-660 \mathrm{~nm}$ wavelengths and a flow rate of approximately $10 \mathrm{~mL} / \mathrm{min}$. Alternatively, one can use a standard spectrophotometer with a flow cuvette, such as a Helma model 178-010-10-40 (10 mm pathlength, $80 \mu \mathrm{L}$ internal volume).

Three setups of the phosphate analyzer were found useful for standard, high-sensitivity, and low dead-time measurements (Figure 1A-C). A five-fold increase in sensitivity was achieved in version $B$ by interchanging the sample and molybdate tubings on the pump (Figure 1B). As the response is linear up to approximately 0.5 absorbance unit, the photometer sensitivity is adjusted to 0.5 absorbance unit per recorder scale in the standard mode (version A) and down to 0.1 unit in the high-sensitivity mode (version B). These settings correspond to approximately 100 and $4 \mu \mathrm{M} \mathrm{P}_{\mathrm{i}}$, respectively, per recorder scale. As each $\mathrm{PP}_{\mathrm{i}}$ molecule yields 2 molecules of $P_{i}$, this sensitivity is sufficient for a reliable measurement of initial velocities at $\mathrm{PP}_{\mathrm{i}}$ concentrations down to $0.5 \mu \mathrm{M}$ (see Appendix A for further details). PPase concentration in the assay is typically in the pM range when activity is determined 
at saturating substrate concentrations and optimal $\mathrm{pH}$ and temperature values. We have successfully used the phosphate analyzer to determine PPase reaction kinetics over a broad temperature range (reaction mixture temperature $20-60{ }^{\circ} \mathrm{C}$ ).

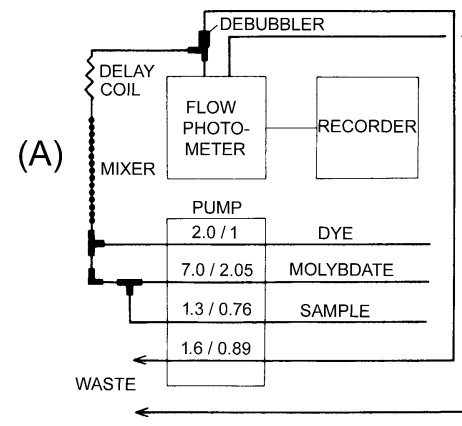

(B)
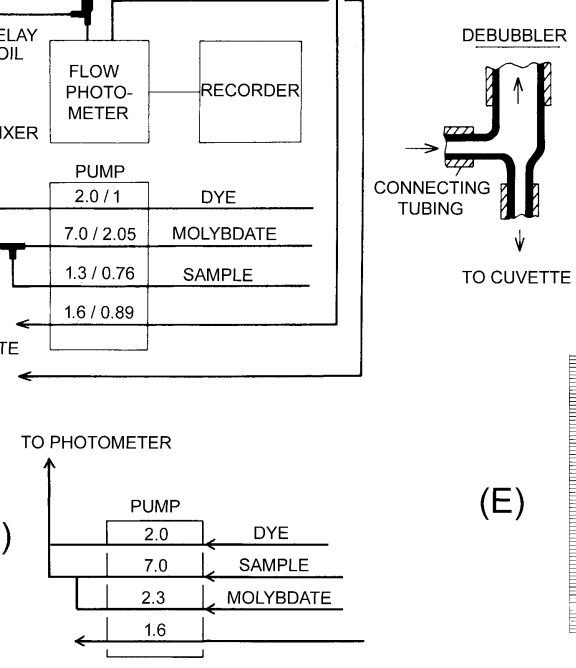

(D)

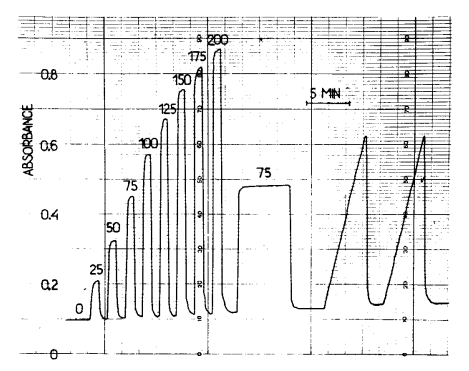

(E)

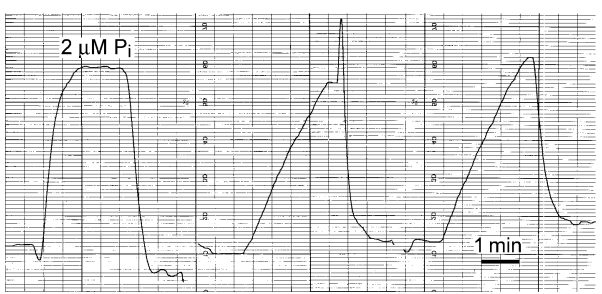

(F)

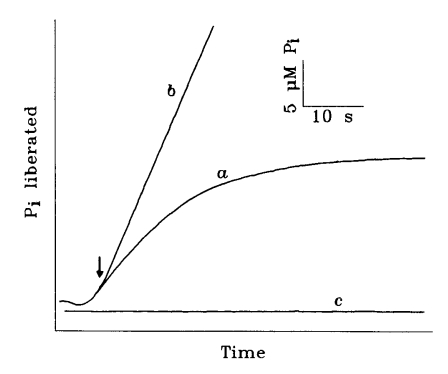

Figure 1. The phosphate analyzer is used to assay PPase activity in a continuous way. (A) Flow diagram for the phosphate analyzer in standard mode; (B) Tubing connections on the pump in the high-sensitivity mode; (C) tubing connections in the low dead-time mode. Numbers on the pump refer to flow rate in $\mathrm{mL} / \mathrm{min}$ (before the slash) and tubing diameter in $\mathrm{mm}$ (panel A) or flow rate in $\mathrm{mL} / \mathrm{min}$ (panels B and C). (D) Actual $\mathrm{P}_{\mathrm{i}}$ accumulation recordings in setup A with photometer sensitivity of 1 absorbance unit per recorder scale. The calibration data shown at the beginning of the recording was obtained by adding $0-200 \mu \mathrm{M} \mathrm{P}_{\mathrm{i}}$ to the reaction buffer. (E) Actual $\mathrm{P}_{\mathrm{i}}$ accumulation recordings in setup B with photometer sensitivity of 0.1 absorbance unit per recorder scale. The assay mixture of $40 \mathrm{~mL}$ volume contained $140 \mu \mathrm{M} \mathrm{PP}, 5 \mathrm{mM}$ $\mathrm{MgCl}_{2}, 50 \mathrm{mM}$ MOPS-KOH, pH 7.2, and $0.03 \mathrm{nM}$ Streptococcus gordonii PPase with a specific activity of $480 \mathrm{~s}^{-1}$. (F) Actual recordings of $\mathrm{P}_{\mathrm{i}}$ accumulation in the setup $\mathrm{C}$ for rat liver PPase in the presence (a) or absence (b) of slow-binding inhibitor (10 mM fluoride). The arrow marks the moment of enzyme addition. Part of the figure was taken with permission from references [13] (panels A and D) and [14] (panels C and F).

The dead-time between withdrawing the sample and mixing it with acid/molybdate is $10 \mathrm{~s}$ in the standard mode but can be decreased to $1 \mathrm{~s}$ by shifting the first mixing point to the pump inlet (Figure 1C). In this version, the sample is withdrawn from the reaction vessel at a rate of $1.2 \mathrm{~mL} / \mathrm{min}$ due to differences in the two lowest pump tubes' flow rates. This setup helps monitor reactions demonstrating nonlinear progress curves because of enzyme activation or inactivation during the reaction. Reagent concentrations were adjusted in versions $B$ and $C$ as indicated in Table 1 to ensure the same optimal final concentrations in the photometer cuvette. 
Table 1. Assays measuring $\mathrm{PP}_{\mathrm{i}}$ hydrolysis. Instrument setups for the continuous assay versions $\mathrm{A}-\mathrm{C}$ are shown in Figure $1 \mathrm{~A}-\mathrm{C}$.

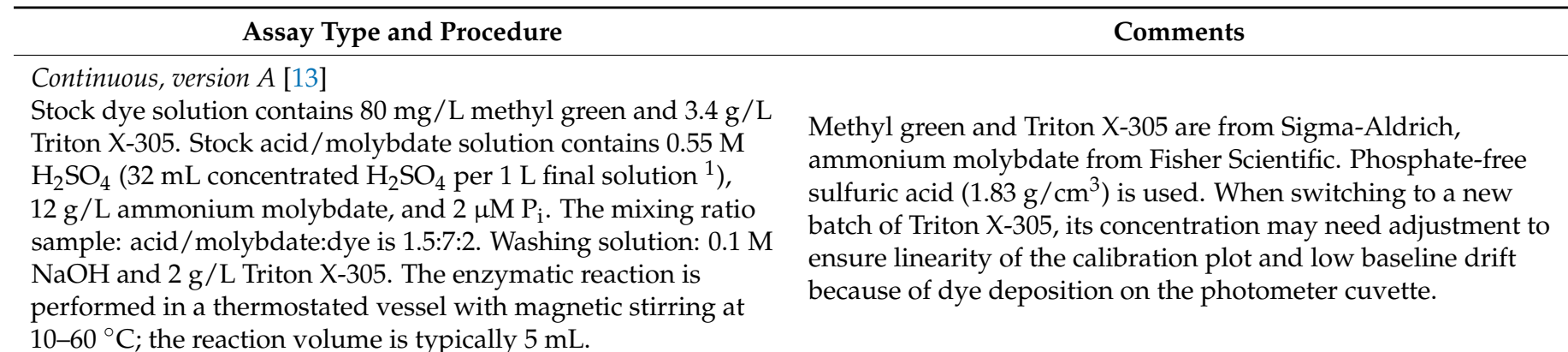

Continuous, version $B$ [13]

Stock dye solution contains $86 \mathrm{mg} / \mathrm{L}$ methyl green and $3.7 \mathrm{~g} / \mathrm{L}$

Triton X-305. Stock acid/molybdate solution contains $1.8 \mathrm{M}$

$\mathrm{H}_{2} \mathrm{SO}_{4}$ (105 mL concentrated $\mathrm{H}_{2} \mathrm{SO}_{4}$ per $1 \mathrm{~L}$ final solution),

$39 \mathrm{~g} / \mathrm{L}$ ammonium molybdate, and $7 \mu \mathrm{M} \mathrm{P}$. The mixing ratio

Acid-resistant Iso-Versinic tubing is preferable on the pump for the acid/molybdate solution in this case. sample:acid/molybdate:dye is 7:2.3:2. The PPase reaction volume is typically $25-40 \mathrm{~mL}$.

\footnotetext{
Continuous, version C [14]

Stock dye solution contains $30 \mathrm{mg} / \mathrm{L}$ methyl green and $1.3 \mathrm{~g} / \mathrm{L}$

Triton X-305. Stock acid/molybdate solution contains $1.0 \mathrm{M}$

$\mathrm{H}_{2} \mathrm{SO}_{4}$ (59 mL concentrated $\mathrm{H}_{2} \mathrm{SO}_{4}$ per $1 \mathrm{~L}$ final solution),

$22 \mathrm{~g} / \mathrm{L}$ ammonium molybdate, and $4 \mu \mathrm{M} \mathrm{P}_{\mathrm{i}}$. The mixing ratio

sample: acid/molybdate:dye is 1.2:3.2:4.4.
}

\section{Fixed-time $[15,16]$}

Stock dye/molybdate solution (stable for months in a refrigerator): $115 \mathrm{mg}$ of malachite green are dissolved in $100 \mathrm{~mL}$ of $2.5 \mathrm{M} \mathrm{H}_{2} \mathrm{SO}_{4}$, followed by $1.4 \mathrm{~g}$ of ammonium molybdate. On the day of use, $0.25 \mathrm{~mL}$ of $10 \%$ Tween-20 $(w / w)$ is added per $10 \mathrm{~mL}$ of the dye/molybdate solution. The PPase reaction is performed in a total volume of $0.2 \mathrm{~mL}$ in 96-well plates and terminated by adding $0.05 \mathrm{~mL}$ of the color reagent. Absorbance at $630 \mathrm{~nm}$ is measured after $10 \mathrm{~min}$.

\footnotetext{
${ }^{1}$ Note: dilution of sulfuric acid generates much heat, which may cause boiling/spilling. It is advised to add the acid slowly to water in a Duran/Pyrex glass beaker in a fume hood.
}

Malachite green is from Sigma-Aldrich, Tween-20 from Ferak Berlin. Tween-20 $(0.05 \%, w / w)$ can be added instead to the PPase assay mixture, which typically contains $0.05 \mathrm{M}$ Tris- $\mathrm{HCl}$ or another buffer, $0.05 \mathrm{mM} \mathrm{PP}_{\mathrm{i}}$, and $5 \mathrm{mM} \mathrm{MgCl}_{2}$.

The continuous $P_{\mathrm{i}}$ assay is robust and tolerates the presence of many biochemical compounds, including magnesium ions at high concentrations (up to $40 \mathrm{mM}$ ). In contrast, $\mathrm{Mg}^{2+}$ interferes with the $\mathrm{P}_{\mathrm{i}}$ assay based on 12-molibdophosphoric acid reduction [17]. Nevertheless, it is wise to calibrate the instrument by measuring phosphate standard against background each time when a new component is added to the sample assayed, especially when working in the high-sensitivity mode (version B). Importantly, $\mathrm{PP}_{\mathrm{i}}$ at high concentrations was found to suppress the $\mathrm{P}_{\mathrm{i}}$ signal (by $25 \%$ for $1.5 \mathrm{mM} \mathrm{PP} \mathrm{P}_{\mathrm{i}}$ ) in this mode. This should be taken into consideration in measurements of PPase activity at a variable substrate concentration. The effect is proportional to $\mathrm{PP}_{\mathrm{i}}$ concentration and likely results from the competitive formation of 12-molibdopyrophosphoric acid, detected by Raman spectroscopy [18].

Other known continuous assays of PPase activity monitor, depending on $\mathrm{pH}$, uptake or release of hydrogen ions during $\mathrm{PP}_{\mathrm{i}}$ conversion to $\mathrm{P}_{\mathrm{i}}[19,20]$ or monitor $\mathrm{PP}_{\mathrm{i}}$ concentration using synthetic $\mathrm{PP}_{\mathrm{i}}$ sensors [21-25]. These assays are less sensitive and less convenient in that the signal is not proportional to the degree of conversion.

Substances that modulate PPase activity will interfere with any assay. Among them, Tris and other amine buffers were found to dramatically increase the Michaelis constant for family I and membrane PPases [26-28]. Accordingly, zwitterionic buffers, such as Tes, Mops, and HEPES, are preferable for work at sub- $K_{\mathrm{m}}$ substrate concentrations. Tetramethy- 
lammonium hydroxide was found to be useful as the second component of the zwitterionic buffers in experiments measuring $\mathrm{K}^{+}$and $\mathrm{Na}^{+}$effects on $\mathrm{K}^{+}$-dependent membrane PPase. However, some batches of this strongly basic compound supplied in glass containers were found to nonspecifically inactivate this enzyme when used as a buffer component instead of $\mathrm{KOH}$.

\section{Sensitive Fixed-Time Assay of $\mathbf{P P}_{\mathbf{i}}-\mathrm{Hydrolyzing}$ Activity}

Fixed-time assays measuring the product $P_{i}$ are perhaps most suitable for highthroughput screening of compound libraries for the effects on PPase activity. Most published procedures determine $P_{i}$ as reduced 12-molybdophosphoric acid [29] and perform well with $10^{-5}-10^{-4} \mathrm{M} \mathrm{P}_{\mathrm{i}}$ concentrations. Although this sensitivity suffices for most applications, the identification of samples with low PPase activity or assays performed at low $\mathrm{PP}_{\mathrm{i}}$ concentrations $(<10 \mu \mathrm{M})$ would require a more sensitive $\mathrm{P}_{\mathrm{i}}$ assay, such as the assay based on the shift of malachite green spectrum upon binding to 12-molybdophosphoric acid. However, low dye solubility, leading to its precipitation, was a serious drawback of the original malachite green-based procedure [30] and its many later variants.

A solution to this problem was finding that increased acid concentration $\left(2.5 \mathrm{M} \mathrm{H}_{2} \mathrm{SO}_{4}\right)$ in stock dye solution surprisingly increases dye solubility and stability [15]. This finding allowed the formulation of a single stable color reagent that stops the enzymatic reaction and produces a green-blue color $(630 \mathrm{~nm})$, whose intensity is proportional to $P_{i}$ concentration. The color reagent is made daily by adding the nonionic detergent Tween-20 (color stabilizer) to the stock dye/molybdate solution (Table 1 ). The signal produced by $2 \mu \mathrm{M}$ $\mathrm{P}_{\mathrm{i}}$ (corresponding to $1 \mu \mathrm{M} \mathrm{PP} \mathrm{P}_{\mathrm{i}}$ hydrolyzed) is 0.15 absorbance units in a $1 \mathrm{~cm}$ cuvette. The assay can be performed in a 96-well plate (Figure 2) and quantified with a plate reader.

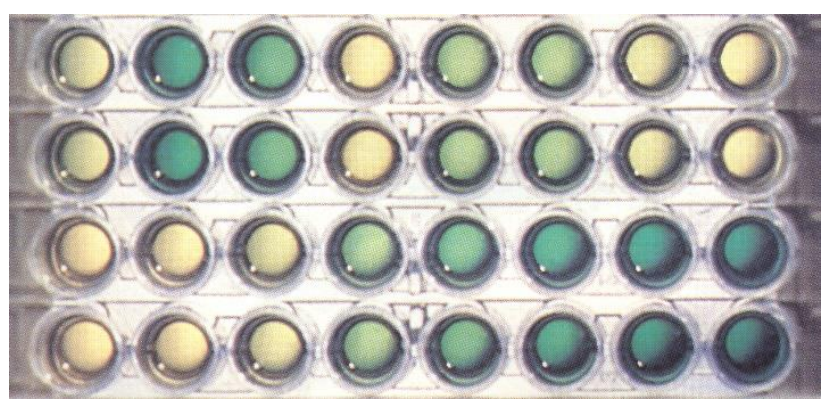

Figure 2. PPase assay using the malachite green procedure. Two bottom rows show a duplicate series of phosphate dilutions from $0 \mu \mathrm{M}$ (left) to $10 \mu \mathrm{M}$ (right). Two top rows show typical results of a duplicate screening test of a library of potential inhibitors of Escherichia coli PPase. The yellow color indicates strong inhibition, dark green color-no inhibition.

\section{Continuous and Fixed-Time Assays of $\mathbf{P P}_{\mathrm{i}}$-Synthesizing Activity}

Like any catalyst, PPase accelerates the attainment of thermodynamic equilibrium $\mathrm{PP}_{\mathrm{i}} \leftrightarrows$ $2 \mathrm{P}_{\mathrm{i}}$ in both directions. Although the equilibrium is shifted to the right $\left(\Delta \mathrm{G}^{0}=-20-25 \mathrm{~kJ} / \mathrm{mol}\right)$, it allows the formation of measurable amounts of $\mathrm{PP}_{\mathrm{i}}$ under physiological conditions. For instance, the concentration of $\mathrm{PP}_{\mathrm{i}}$ at equilibrium with $10 \mathrm{mM} \mathrm{P} \mathrm{i}_{\mathrm{i}}\left(\mathrm{pH} \mathrm{7,25}{ }^{\circ} \mathrm{C}, 1 \mathrm{mM}\right.$ $\mathrm{Mg}^{2+}$ ) is approximately $1 \mu \mathrm{M}$ [31], which is below the detection limits of most analytical methods for $\mathrm{PP}_{\mathrm{i}}$ determination. However, micromolar sensitivity has been claimed for several assays based on fluorogenic and electrochemical $\mathrm{PP}_{\mathrm{i}}$ sensors [21-25]. Some of them are commercially available. However, they are of limited use in measurements of initial velocities of $\mathrm{PP}_{\mathrm{i}}$ synthesis, which require that $\mathrm{PP}_{\mathrm{i}}$ concentration in the medium does not exceed $10 \%$ of the equilibrium concentration to prevent product inhibition.

This problem is elegantly obviated in the coupled-enzyme luminescent procedure of Nyrén and Lundin [32], which later became a core element of "pyrosequencing", a wellestablished DNA sequencing method [33]. In their procedure, $\mathrm{PP}_{\mathrm{i}}$ is converted to ATP by reaction with adenosine-5'-phosphosulfate (APS), catalyzed by ATP sulfurylase (E.C. 
2.7.7.4), and the ATP formed is detected with a firefly luciferase/luciferin system. This method is used in three versions in PPase studies (Table 2 and Figure 3). In the first version, all components of the detection system, including ATP sulfurylase, luciferase, APS, and luciferin, are added to the PPase assay mix, and $\mathrm{PP}_{\mathrm{i}}$ formation is recorded continuously. This became possible because neither APS nor luciferin affects PPase activity, and both ATP sulfurylase and PPase need $\mathrm{Mg}^{2+}$ as a cofactor. The synthesized $\mathrm{PP}_{\mathrm{i}}$ is continuously converted into ATP at such a high rate that the steady-state $\mathrm{PP}_{\mathrm{i}}$ level is not inhibitory for PPase and luciferase activities. This is ensured by maintaining high ATP sulfurylase concentration, such that its doubling does not increase the measured rate of ATP accumulation. In the second assay version, the PPase reaction mix contains ATP sulfurylase/APS, which continuously converts the formed $\mathrm{PP}_{\mathrm{i}}$ into ATP, whose concentration is determined at fixed time points with luciferase/luciferin in a separate tube. Importantly, PPase does not hydrolyze ATP in the presence of $\mathrm{Mg}^{2+}$. Both assay versions combine the high sensitivity of the luciferase ATP determination with the possibility to accumulate detectable amounts of ATP while keeping the steady-state concentration of $\mathrm{PP}_{\mathrm{i}}$ at a sub-equilibrium, non-inhibitory level. ATP sulfurylase and luciferase act thus as amplifiers of the $\mathrm{PP}_{\mathrm{i}}$-generated signal and allow the measurement of the initial velocities of $\mathrm{PP}_{\mathrm{i}}$ synthesis from $\mathrm{P}_{\mathrm{i}}$.

Table 2. Assays measuring $\mathrm{PP}_{\mathrm{i}}$ formation.

\begin{tabular}{|c|c|}
\hline Assay Type and Procedure & Comments \\
\hline $\begin{array}{l}P P_{i} \text { synthesis (continuous) [34] } \\
\text { Assay mixture contains calculated amounts of potassium } \\
\text { phosphate and } \mathrm{MgCl}_{2}, 0.7 \mathrm{U} / \mathrm{mL} \text { ATP-sulfurylase, } 10 \mu \mathrm{M} \text { APS, } \\
5 \mu \mathrm{L} \text { of luciferin } / \mathrm{luciferase} \text { solution (Sigma ATP assay mix, } \\
\text { catalog no. FLAAM, reconstituted with } 5 \mathrm{~mL} \text { of water), } 1 \mathrm{mM} \\
\text { dithiothreitol, } 0.8 \mathrm{mg} / \mathrm{mL} \text { bovine serum albumin and } 0.1 \mathrm{M} \\
\text { MOPS-KOH buffer in a total volume of } 0.2 \mathrm{~mL} \text {. The reaction is } \\
\text { initiated by adding PPase, and the time-course of luminescence } \\
\text { is followed with a luminometer (e.g., LKB model } 1250 \text { ). After } \\
\text { the PP } \mathrm{PP}_{\mathrm{i}} \text {-generated signal stabilizes, } 2 \mu \mathrm{L} \text { of } 10 \mu \mathrm{M} \text { ATP are } \\
\text { added for internal calibration. }\end{array}$ & $\begin{array}{l}\text { ATP sulfurylase is from BioLabs (UK). Its concentration should } \\
\text { be sufficiently high so that its doubling does not change the } \\
\text { measured rate of ATP accumulation. } \\
\text { The luminescence-versus-time dependencies are slightly curved } \\
\text { because of the slow inactivation of luciferase in the } \\
\text { reaction medium. }\end{array}$ \\
\hline
\end{tabular}

$P P_{i}$ synthesis (fixed-time) [35]

Assay mixture contains calculated amounts of potassium phosphate and $\mathrm{MgCl}_{2}, 0.7 \mathrm{U} / \mathrm{mL}$ ATP-sulfurylase, $10 \mu \mathrm{M}$ APS, and $0.1 \mathrm{M}$ MOPS-KOH buffer in a total volume of $100 \mu \mathrm{L}$. The reaction is initiated by adding PPase and carried out for $10 \mathrm{~min}$. Aliquots $(15 \mu \mathrm{L})$ are withdrawn at various times, quenched with $15 \mu \mathrm{L}$ of $1 \mathrm{M}$ trifluoroacetic acid, incubated for $4 \mathrm{~min}$ at room temperature, and neutralized with $15 \mu \mathrm{L}$ of $1.5 \mathrm{M}$ Tris. The ATP formed is quantitated by adding $10 \mu \mathrm{L}$ of the mixture to $200 \mu \mathrm{L}$ of $0.2 \mathrm{M}$ Tris- $\mathrm{HCl}$ buffer, $\mathrm{pH} 8.0$ containing $6 \mu \mathrm{L}$ of the luciferin/luciferase solution (Sigma ATP assay mix, catalog No. FLAAAM, reconstituted with $5 \mathrm{~mL}$ of water) and measuring the luminescence. After the signal stabilizes, $2 \mu \mathrm{L}$ of $10 \mu \mathrm{M}$ ATP are added for internal calibration.

Crystalline phosphoric acid (Fluka) is freed from $\mathrm{PP}_{\mathrm{i}}$ contamination as described in the text.

\section{Enzyme-bound $P P_{i}$ formation [36]}

PPase (typically 20-100 $\mu \mathrm{M}$ ) is preequilibrated with $\mathrm{P}_{\mathrm{i}}$ and $\mathrm{Mg}^{2+}$ under appropriate conditions in a $50 \mu \mathrm{L}$ volume and quenched with $10 \mu \mathrm{L}$ of $5 \mathrm{M}$ trifluoroacetic acid. After several minutes, precipitated protein is removed by centrifugation, a $10 \mu \mathrm{L}$ aliquot of the supernatant is added to $0.2 \mathrm{~mL}$ of the $\mathrm{PP}_{\mathrm{i}}$ assay cocktail (0.2 M Tris- $\mathrm{HCl}, \mathrm{pH} 8.0,0.4 \mathrm{U} / \mathrm{mL}$ ATP sulfurylase, $10 \mu \mathrm{M}$ APS, $6 \mu \mathrm{L}$ of the luciferase/luciferin solution, $1 \mathrm{mM}$ dithiothreitol, $0.8 \mathrm{mg}$ bovine serum albumin, $30 \mu \mathrm{M}$ EGTA), and the luminescence is recorded. After the signal stabilizes, $2 \mu \mathrm{L}$ of $10 \mu \mathrm{M} \mathrm{PP}{ }_{i}$ are added for internal calibration.
Determined $\mathrm{PP}_{\mathrm{i}}$ content refers to the sum of enzyme-bound and medium $\mathrm{PP}_{\mathrm{i}}$. The latter is measured similarly but using a 100 times lower enzyme concentration and subtracted. 
(A)

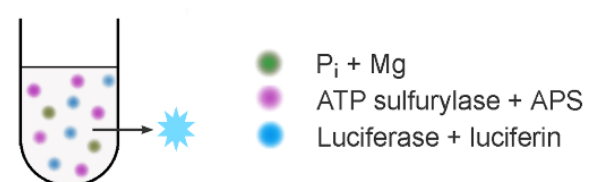

(B)

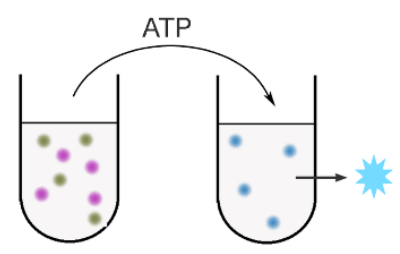

(C)

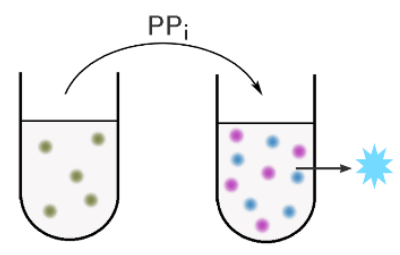

(D)

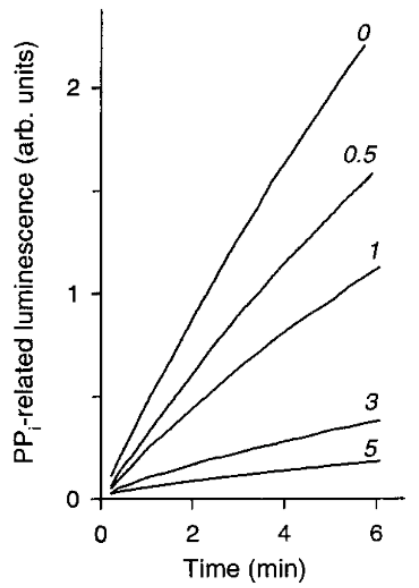

Figure 3. Schematics of the assays to measure PPase-catalyzed $\mathrm{PP}_{\mathrm{i}}$ synthesis. (A) A continuous assay of the medium $\mathrm{PP}_{\mathrm{i}}$ synthesis; (B) fixed-time assay of the medium $\mathrm{PP}_{\mathrm{i}}$ synthesis; $(\mathbf{C})$ determination of enzyme-bound $\mathrm{PP}_{\mathrm{i}}$. The assayed PPase is added to all far-left tubes. Three other major components are shown as colored spots. The principal analytes transferred between the tubes are indicated above the arrows. The blue star refers to the luminescence signal. (D) Actual $\mathrm{PP}_{\mathrm{i}}$ accumulation recordings in the assay version A for baker's yeast PPase in the presence of slow-binding inhibitor (fluoride; its concentrations in $\mathrm{mM}$ are indicated on the curves). Panel D was taken with permission from reference [34].

The third version of the $\mathrm{PP}_{\mathrm{i}}$ assay accesses the equilibrium of the $\mathrm{PP}_{\mathrm{i}} \leftrightarrows 2 \mathrm{P}_{\mathrm{i}}$ reaction in the active site of PPase. This information is required to estimate the rate constants for individual steps of PPase catalysis $[37,38]$. This equilibrium is markedly shifted to the left by comparing the equilibrium in solution-up to $20 \%$ of enzyme-bound $P_{i}$ is converted to $\mathrm{PP}_{\mathrm{i}}$ [37,38]. To assay, the enzyme-bound $\mathrm{PP}_{\mathrm{i}}$, the enzyme $(20-100 \mu \mathrm{M})$ is incubated with $\mathrm{P}_{\mathrm{i}}$ and $\mathrm{Mg}^{2+}$, inactivated by trifluoroacetic acid to release enzyme-bound $\mathrm{PP}_{\mathrm{i}}$ into solution, and an aliquot is taken to assay $\mathrm{PP}_{\mathrm{i}}$ using the coupled ATP sulfurylase/luciferase procedure.

Several comments on the assay procedure are appropriate. First, phosphoric acid and its salts are often contaminated with $\mathrm{PP}_{\mathrm{i}}$, leading to high background luminescence. A low-PP $\mathrm{P}_{\mathrm{i}}$ potassium phosphate can be prepared in the following way: phosphoric acid is diluted to $0.2 \mathrm{M}$ with water, boiled for $3 \mathrm{~h}$, and neutralized with $\mathrm{KOH}$ [39]. Second, low but significant background luminescence results from APS being a poor substrate for luciferase. Third, as $P_{i}$ is added in high concentrations, care should be taken to ensure the assay mixture's desired $\mathrm{pH}$. It is not enough to adjust to this value the $\mathrm{pH}$ of the stock $\mathrm{P}_{\mathrm{i}}$ solution because the formation of the $\mathrm{MgHPO}_{4}$ complex from $\mathrm{H}_{2} \mathrm{PO}_{4}{ }^{-}$upon mixing stock $\mathrm{P}_{\mathrm{i}}$ and $\mathrm{Mg}^{2+}$ solutions would cause acidification of the medium (by $0.10 \mathrm{pH}$ unit with $50 \mathrm{mM} \mathrm{P}_{\mathrm{i}}, 5 \mathrm{mM} \mathrm{Mg}^{2+}$ in $0.1 \mathrm{M}$ MOPS-KOH buffer, $\mathrm{pH}$ 7.2). This effect is compensated by adding an appropriate amount of $\mathrm{KOH}$ to the assay mixture. An Excel subroutine to calculate this amount, which depends on $\mathrm{P}_{\mathrm{i}}, \mathrm{Mg}^{2+}$, and $\mathrm{H}^{+}$concentrations and reaction volume, is available (Supplementary Material). Alternatively, one can adjust the $\mathrm{pH}$ of the stock $\mathrm{P}_{\mathrm{i}}$ solution used at each $\mathrm{Mg}^{2+}$ concentration to the value (above the desired assay $\mathrm{pH})$ determined in a trial titration.

A different coupled-enzyme assay with similar characteristics has been described [40]. In this assay, $\mathrm{PP}_{\mathrm{i}}$ is converted to adenosine $5^{\prime}$-triphosphate (ATP) by pyruvate phosphate dikinase in the presence of its substrates, pyruvate phosphate and AMP. The ATP formed is similarly determined by the firefly luciferase reaction. The detection limit for $\mathrm{PP}_{\mathrm{i}}$ is approximately $10^{-8} \mathrm{M}$. The use of this assay in PPase studies has not yet been reported. 


\section{Ionic Equilibria in the Assay Media}

Magnesium, the essential cofactor of PPases, has a dual role in catalysis-it activates the enzyme and substrates by forming complexes with both. Because the enzyme can sense only the actual substrate species in the medium, but not total substrate concentration, the magnesium complexes of the substrates $\mathrm{PP}_{\mathrm{i}}$ and $\mathrm{P}_{\mathrm{i}}$ are named "true substrates." A meaningful analysis of enzyme kinetics with the Michaelis-Menten equation should be done in terms of these true substrates. Furthermore, the substrate-concentration dependencies of enzyme activity should be measured at a fixed free $\mathrm{Mg}^{2+}$ ion concentration because it, not the total magnesium concentration, determines the fraction of the metal-complexed enzyme and, hence, its activity.

Pyrophosphoric acid undergoes a four-step dissociation, of which only the last two steps with the $\mathrm{p} K_{\mathrm{a} 3}$ of 6.38 and $\mathrm{p} K_{\mathrm{a} 4}$ of 9.11 should be considered in enzyme studies. Magnesium forms four complexes with three $\mathrm{PP}_{\mathrm{i}}$ species: $\mathrm{MgP}_{2} \mathrm{O}_{7}{ }^{2-}, \mathrm{Mg}_{2} \mathrm{P}_{2} \mathrm{O}_{7}, \mathrm{MgHP}_{2} \mathrm{O}_{7}{ }^{-}$ and $\mathrm{MgH}_{2} \mathrm{P}_{2} \mathrm{O}_{7}$ (Scheme 1). Furthermore, alkali metal ions, often present in the assay medium, form additional complexes: $\mathrm{MP}_{2} \mathrm{O}_{7}{ }^{3-}, \mathrm{M}_{2} \mathrm{P}_{2} \mathrm{O}_{7}{ }^{2-}$ and $\mathrm{MHP}_{2} \mathrm{O}_{7}{ }^{2-}\left(\mathrm{M}=\mathrm{K}^{+}\right.$or $\mathrm{Na}^{+}$). At fixed $\mathrm{pH}$ and alkali metal ion concentrations, the complexation in this system can be described by simple Scheme 2, in which each species is the sum of all differently protonated individual species of the same magnesium: $\mathrm{PP}_{\mathrm{i}}$ stoichiometry.

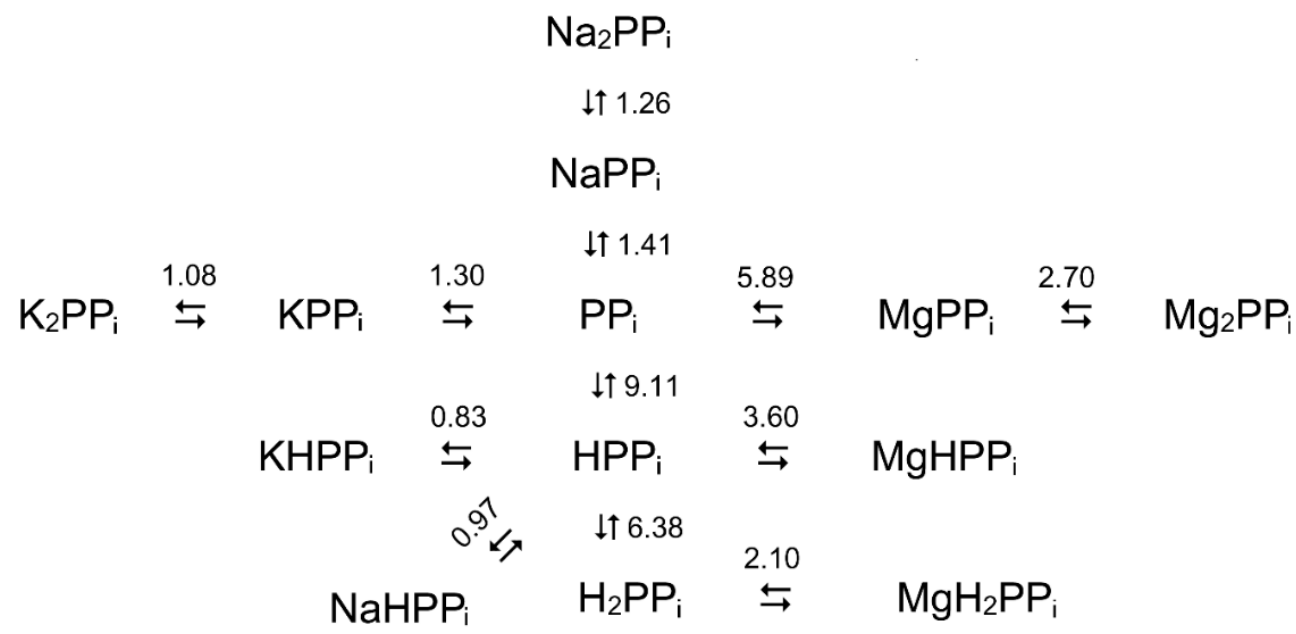

Scheme 1. Complex formation between $\mathrm{PP}_{\mathrm{i}}, \mathrm{H}^{+}, \mathrm{Mg}^{2+}, \mathrm{K}^{+}$and $\mathrm{Na}^{+}$ions under physiological conditions. The number above or beside arrows refers to the minus logarithm of the respective dissociation constant [41].

$$
\mathrm{PP}_{\mathrm{i}} \stackrel{K_{\mathrm{mpp}}}{\leftrightarrows} \mathrm{MgPP}_{\mathrm{i}} \stackrel{K_{\mathrm{m} 2 \mathrm{pp}}}{\leftrightarrows} \mathrm{Mg}_{2} \mathrm{PP}_{\mathrm{i}}
$$

Scheme 2. A simplified description of complexation between $\mathrm{PP}_{\mathrm{i}}$ and $\mathrm{Mg}^{2+}$ at fixed $\mathrm{pH}$ and alkali metal ion concentrations.

The values of $K_{\mathrm{mpp}}$ and $K_{\mathrm{m} 2 \mathrm{pp}}$ can be calculated at each $\mathrm{pH}$ value and alkali metal concentration from the dissociation constants of the individual $\mathrm{PP}_{\mathrm{i}}$ complexes with $\mathrm{H}^{+}$, $\mathrm{Mg}^{2+}, \mathrm{K}^{+}$and $\mathrm{Na}^{+}$(tabulated in a previous publication [41]). Knowing the values of $K_{\mathrm{mpp}}$ and $K_{\mathrm{m} 2 \mathrm{pp}}$ allows calculating the total magnesium and $\mathrm{PP}_{\mathrm{i}}$ concentrations needed to maintain the required concentrations of $\mathrm{MgPP}_{\mathrm{i}}$ or $\mathrm{Mg}_{2} \mathrm{PP}_{\mathrm{i}}$ complex and free $\mathrm{Mg}^{2+}$. This algorithm was embedded in an Excel subroutine that calculates the composition of the assay medium at $25^{\circ} \mathrm{C}$ and chosen $\mathrm{pH}$ and alkali metal concentrations (Supplementary Material).

The choice between $\mathrm{MgPP}_{\mathrm{i}}$ and $\mathrm{Mg}_{2} \mathrm{PP}_{\mathrm{i}}$ as the true substrate is largely arbitrary because the ratio of $\mathrm{Mg}_{2} \mathrm{PP}_{\mathrm{i}}$ and $\mathrm{MgPP}_{\mathrm{i}}$ concentrations is constant at a fixed $\mathrm{Mg}^{2+}$ concentration, and switching from one complex to the other would only change the apparent value of the Michaelis constant. In most reported studies, $\mathrm{MgPP}_{\mathrm{i}}$ has been assumed to be the true substrate for PPases of families I and II and $\mathrm{Mg}_{2} \mathrm{PP}_{\mathrm{i}}$ to be such for membrane 
PPases. However, one should keep in mind that steady-state kinetic studies can define only stoichiometry of the statistically significant enzyme species, but not the ways of their formation because schemes assuming different true substrates will lead to the same rate law and are, therefore, indistinguishable. These considerations are especially important to remember when working with the kinetic schemes considering both substrate and $\mathrm{Mg}^{2+}$ binding to the enzyme.

$\mathrm{P}_{\mathrm{i}}$ is represented by a mixture of $\mathrm{H}_{2} \mathrm{PO}_{4}{ }^{-}$and $\mathrm{HPO}_{4}{ }^{2-}$ forms in the $\mathrm{pH}$ range 4-10, and only the latter species forms 1:1 complexes with $\mathrm{Mg}^{2+}, \mathrm{K}^{+}$, and $\mathrm{Na}^{+}$(Scheme 3). The $\mathrm{MgP}_{\mathrm{i}}$ complex is generally assumed to be the true substrate in the PPase-catalyzed $\mathrm{PP}_{\mathrm{i}}$ synthesis. The total concentrations of $\mathrm{Mg}^{2+}$ and $\mathrm{P}_{\mathrm{i}}$ needed to maintain the required concentrations of the $\mathrm{MgP}_{\mathrm{i}}$ complex and free $\mathrm{Mg}^{2+}$ ions are calculated using the apparent dissociation constant for $\mathrm{MgP}_{\mathrm{i}}$. The latter is obtained similarly at each $\mathrm{pH}$ value and alkali metal concentration from the dissociation constants of the individual $P_{i}$ complexes with $\mathrm{H}^{+}, \mathrm{Mg}^{2+}, \mathrm{K}^{+}$and $\mathrm{Na}^{+}$[42-45]. This algorithm was also embedded in an Excel subroutine (Supplementary Material), which additionally calculates the amount of the alkali needed to compensate for the acidification of the assay medium because of the selective complexation of the $\mathrm{HPO}_{4}{ }^{2-}$ species by $\mathrm{Mg}^{2+}$.

\begin{tabular}{|c|c|c|c|c|}
\hline & & $\mathrm{NaHP}_{i}$ & & \\
\hline & 0.51 & $\downarrow \uparrow 0.69$ & 2.22 & \\
\hline $\mathrm{KHP}_{\mathrm{i}}$ & $\stackrel{\leftrightarrows}{\leftrightarrows}$ & $\mathrm{HP}_{\mathrm{i}}$ & $\leftrightarrows$ & $\mathrm{MgHP}_{\mathrm{i}}$ \\
\hline & & $\downarrow \uparrow 6.8$ & & \\
\hline & & $\mathrm{H}_{2} \mathrm{P}_{\mathrm{i}}$ & & \\
\hline
\end{tabular}

Scheme 3. Complex formation between $\mathrm{P}_{\mathrm{i}}, \mathrm{H}^{+}, \mathrm{Mg}^{2+}, \mathrm{K}^{+}$, and $\mathrm{Na}^{+}$ions under physiological conditions. The number above or beside arrows refers to the minus logarithm of the respective dissociation constant [42-45].

Supplementary Materials: The following is available: Microsoft Excel file: Calculations of medium composition.

Author Contributions: Writing_original draft preparation, A.A.B.; software and visualization, V.A.A.; writing-review and editing, A.M.M. All authors have read and agreed to the published version of the manuscript.

Funding: This work was supported by the Academy of Finland (grant numbers 307775 and 335377) and by Lomonosov Moscow State University.

Data Availability Statement: The Excel subroutine that calculates the composition of the assay medium at chosen $\mathrm{pH}$ and alkali metal concentrations is available as Supplementary Material.

Conflicts of Interest: The authors declare no conflict of interest.

\section{Appendix A}

\section{Estimation of Initial Velocities from Product Formation Curves}

If substrate $\left(\mathrm{PP}_{\mathrm{i}}\right)$ concentration remains saturating during the recording time, resulting in a linear time-course, the initial velocity is obtained straightforwardly. However, if substrate consumption exceeds $20 \%$, drawing the tangent to the product accumulation curve by eye may result in a large error in the initial velocity, more commonly underestimating [46] (pp. 80-82). There are two ways to increase the accuracy of such analysis. One can derive the explicit equation or system of equations that describe the integral reaction kinetics and fit it to the product formation curve. A simpler alternative is to use a semi-empirical procedure to manually draw the zero-time tangent to the curve. The procedure described below determines the second point, though, which the tangent must pass, in addition 
to the zero-time point. The required initial information includes the instrument signal (absorbance increase in recorder paper divisions) upon complete substrate conversion $\left(P_{\text {inf }}\right)$. This parameter is calculated from the expected $P_{i}$ concentration upon complete substrate conversion (twice the initial $\mathrm{PP}_{\mathrm{i}}$ concentration) and instrument sensitivity. One will also need an approximate $K_{\mathrm{m}}$ value in terms of total $\mathrm{PP}_{\mathrm{i}}$.

In a reaction with substrate exhaustion, the product accumulation curve will deviate from the tangent at the zero-time point, corresponding to initial velocity (Figure A1). The difference between the two curves $(\Delta P)$ increases with time, and its knowledge at a single value of $P$ suffices to draw the zero-time tangent. The smaller the correction $(\Delta P)$, the more accurate is the initial velocity estimate. Obviously, the $\Delta P$ value will decrease with increasing $P_{\text {inf }}$ and decreasing $P$ and $K_{\mathrm{m}}$ values. The equation for $\Delta P$ is obtained by combining Equation $\mathrm{A} 1$ and Equation $\mathrm{A} 2$, where $V$ is the maximal velocity, $\mathrm{t}$ is time, $K_{\mathrm{m}}$ is the Michaelis constant, and $P_{\text {inf }}$ is the initial substrate concentration. Equation A1 describes product $\left(P_{1}\right)$ accumulation in time in a zero-order reaction proceeding with the rate equal to the enzyme-catalyzed reaction's initial velocity. Equation A2 describes the true integral kinetics of the enzyme-catalyzed reaction [46] (p. 78). At any time point t, $P_{1}=P+\Delta P$, and, accordingly, Equation $\mathrm{A} 3$ is valid. After its rearrangement, one obtains Equation A4, which links $\Delta P$ to $P_{\text {inf }}, P$, and $K_{\mathrm{m}}$ values.

$$
\begin{gathered}
P_{1}=V \mathrm{t} /\left(1+K_{\mathrm{m}} / P_{\text {inf }}\right) \\
A i P / K_{\mathrm{m}}+K_{\mathrm{m}} \ln \left[P_{\text {inf }} /\left(P_{\text {inf }}-P\right)\right]=V \mathrm{t} \\
P / K_{\mathrm{m}}+K_{\mathrm{m}} \ln \left[P_{\text {inf }} /\left(P_{\text {inf }}-P\right)\right]=(P+\Delta P)\left(1+K_{\mathrm{m}} / P_{\text {inf }}\right) . \\
\Delta P=\left\{P+K_{\mathrm{m}} \ln \left[P_{\text {inf }} /\left(P_{\text {inf }}-P\right)\right]\right\} /\left(1+K_{\mathrm{m}} / P_{\text {inf }}\right)-P
\end{gathered}
$$

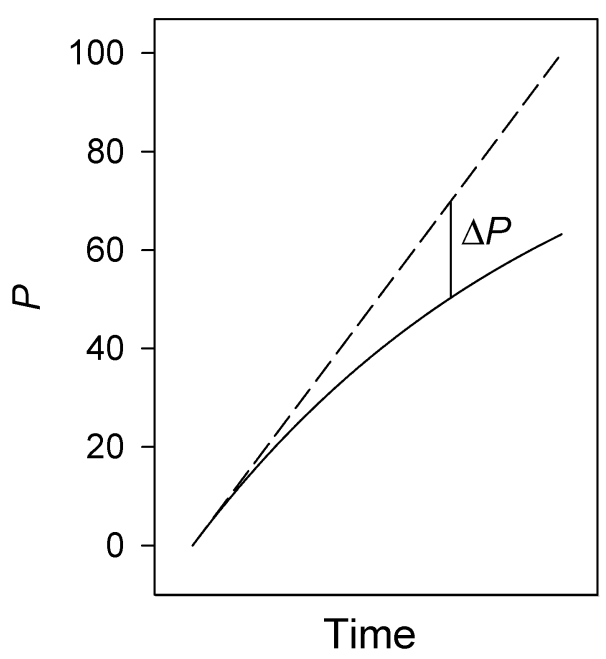

Figure A1. Time-course of product accumulation in the enzyme-catalyzed reaction (solid line). The dashed straight line is the zero-time tangent to the solid curve, with the slope equal to the initial velocity.

The dependencies of $\Delta P$ on $P_{\text {inf }}$ calculated at several fixed $P$ and $K_{\mathrm{m}}$ values are presented in Figure A2. These graphs are used to determine $\Delta P$ at given $P_{\mathrm{inf}}$ and $P$ values and draw the tangent for any reaction with substrate depletion. The top left panel applies to a first-order reaction. As expected, the $\Delta P$ value decreases, and the accuracy of the initial velocity estimate increases accordingly with increasing $P_{\text {inf }}$ and decreasing $P$. Optimally, $P$ should be chosen between 20 and 50\% of $P_{\text {inf }}$, also keeping in mind that the signal-tonoise ratio becomes unfavorable at low $P$ values. Although this treatment involves visual interpolation and is approximate, it decreases the error in the estimated initial velocity to less than $10 \%$, which is sufficient for most uses. The simplicity of the procedure compared 
to that of Cornish-Bowden [47] and other known ones [46] (pp. 80-85) has made it a useful aid in the kinetic studies of PPase. Although we have been mainly using this correction procedure in the continuous assays, it is also applicable to and is especially important for the fixed-time assay carried out at non-saturating substrate concentration.
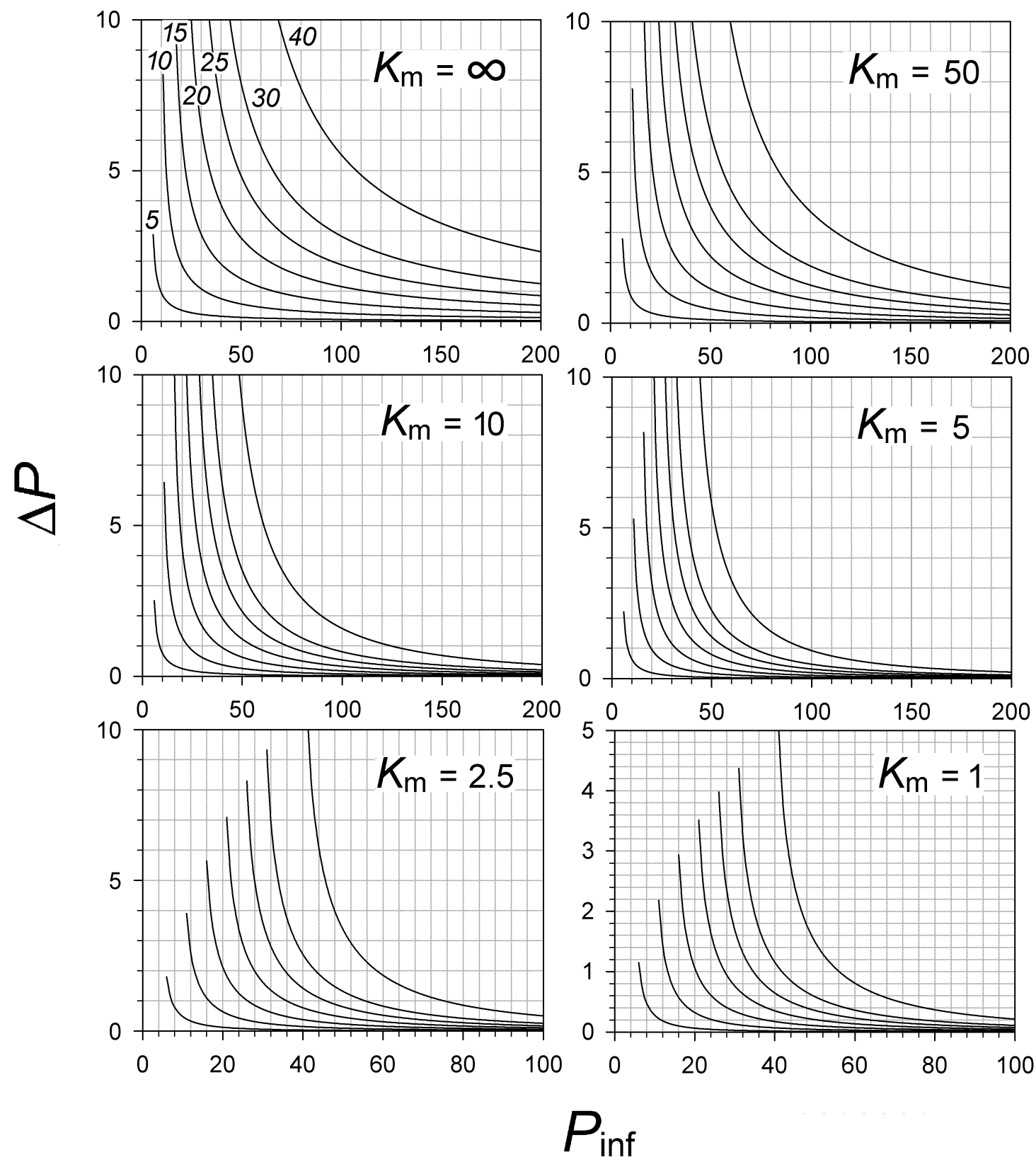

Figure A2. The dependence of $\Delta P$ in Figure A1 on $P_{\text {inf }}$ at seven fixed values of $P$ (shown on one panel and kept same on the other panels) and six values of $K_{\mathrm{m}}$ (shown on the panels) for an enzyme-catalyzed reaction. For simplicity, the values of $\Delta P, P_{\text {inf }}, P$ and $K_{\mathrm{m}}$ are shown in terms of the same arbitrary unit, for instance, recorder paper division. These graphs were created for an enzyme that obeys simple Michaelis-Menten kinetics with the product to substrate ratio of one. To use these graphs for PPase, which produces two $\mathrm{P}_{\mathrm{i}}$ molecules from one $\mathrm{PP}_{\mathrm{i}}$ molecule, one must divide by two the measured values of $P$ and $P_{\text {inf }}$ if they are expressed in terms of $P_{i}$. Note that axis scaling is different on the two bottom panels.

\section{References}

1. Heinonen, J.K. Biological Role of Inorganic Pyrophosphate; Kluwer Academic Publishers: London, UK, 2001.

2. Baykov, A.A.; Malinen, A.M.; Luoto, H.H.; Lahti, R. Pyrophosphate-fueled $\mathrm{Na}^{+}$and $\mathrm{H}^{+}$transport in prokaryotes Microbiol. Mol. Biol. Rev. 2013, 77, 267-276. [CrossRef] [PubMed] 
3. Tsai, J.-Y.; Kellosalo, J.; Sun, Y.-J.; Goldman, A. Proton/sodium pumping pyrophosphatases: The last of the primary ion pumps. Curr. Opin. Struct. Biol. 2014, 27, 38-47. [CrossRef] [PubMed]

4. Gaxiola, R.A.; Regmi, K.; Paez-Valencia, J.; Pizzio, G.; Zhang, S. Plant $\mathrm{H}^{+}$-PPases: Reversible enzymes with contrasting functions dependent on membrane environment. Mol. Plant. 2016, 9, 317-319. [CrossRef] [PubMed]

5. Scholz-Starke, J.; Primo, C.; Yang, J.; Kandel, R.; Gaxiola, R.A.; Hirschi, K.D. The flip side of the Arabidopsis type I protonpumping pyrophosphatase (AVP1): Using a transmembrane $\mathrm{H}^{+}$gradient to synthesize pyrophosphate. J. Biol Chem. 2019, 294, 1290-1299. [CrossRef] [PubMed]

6. Baykov, A.A.; Cooperman, B.S.; Goldman, A.; Lahti, R. Cytoplasmic inorganic pyrophosphatases. Progr. Mol. Subcell. Biol. 1999, 23, 127-150.

7. Kajander, T.K.; Kellosalo, J.; Goldman, A. Inorganic pyrophosphatases: One substrate, three mechanisms. FEBS Lett. 2013, 587, 1863-1869. [CrossRef] [PubMed]

8. Chappelet-Tordo, D.; Fosset, M.; Iwatsuba, M.; Gache, C.; Lazdunski, M. Intestinal alkaline phosphatase: Catalytic properties and half of the sites reactivity. Biochemistry 1974, 13, 1788-1795. [CrossRef]

9. Lee, H.S.; Cho, Y.; Kim, Y.-J.; Lho, T.O.; Cha, S.-S.; Lee, J.-H.; Kang, S.G. A novel inorganic pyrophosphatase in Thermococcus onnurineus NA1. FEMS Microbiol. Lett. 2009, 300, 68-74. [CrossRef]

10. Huang, H.; Patskovsky, Y.; Toro, R.; Farelli, J.D.; Pandya, C.; Almo, S.C.; Allen, K.N.; Dunaway-Mariano, D. Divergence of structure and function in the haloacid dehalogenase enzyme superfamily: Bacteroides thetaiotaomicron BT2127 is an inorganic pyrophosphatase. Biochemistry 2011, 50, 8937-8949. [CrossRef]

11. Baykov, A.A.; Anashkin, V.A.; Salminen, A.; Lahti, R. Inorganic pyrophosphatases of Family II-two decades after their discovery. FEBS Lett. 2017, 591, 3225-3234. [CrossRef] [PubMed]

12. Van Belle, H. New and sensitive reaction for automatic determination of inorganic phosphate and its application to serum. Anal. Biochem. 1970, 33, 132-142. [CrossRef]

13. Baykov, A.A.; Avaeva, S.M. A simple and sensitive apparatus for continuous monitoring of orthophosphate in the presence of acid-labile compounds. Anal. Biochem. 1982, 116, 1-4. [CrossRef]

14. Baykov, A.A.; Alexandrov, A.P.; Smirnova, I.N. A two-step mechanism of fluoride inhibition of rat liver inorganic pyrophosphatase. Arch. Biochem. Biophys. 1992, 294, 238-243. [CrossRef]

15. Baykov, A.A.; Evtushenko, O.A.; Avaeva, S.M. A malachite green procedure for orthophosphate determination and its use in alkaline phosphatase-based enzyme immunoassay. Anal. Biochem. 1988, 171, 266-270. [CrossRef]

16. Baykov, A.A.; Kasho, V.N.; Avaeva, S.M. Inorganic pyrophosphatase as a label in heterogeneous enzyme immunoassay. Anal. Biochem. 1988, 171, 271-276. [CrossRef]

17. Vidilaseris, K.; Kellosalo, J.; Goldman, A. A high-throughput method for orthophosphate determination of thermostable membrane-bound pyrophosphatase activity. Anal. Methods 2018, 10, 646-651. [CrossRef]

18. Himeno, S.; Ueda, T.; Shiomi, M.; Hori, T. Raman studies on the formation of 12-molybdopyrophosphate. Inorg. Chim. Acta 1997, 262, 219-223. [CrossRef]

19. Cooperman, B.S.; Chiu, N.Y.; Bruckmann, R.H.; Bunick, G.J.; McKenna, G.P. Yeast inorganic pyrophosphatase. I. New methods of purification, assay, and crystallization. Biochemistry 1973, 12, 1665-1669. [CrossRef]

20. Shakhov, Y.A.; Nyrén, P. A sensitive and rapid method for determination of pyrophosphatase activity. Acta Chem. Scand. 1982, B36, 689-694. [CrossRef]

21. Kim, S.K.; Lee, D.H.; Hong, J.-I.; Yoon, J. Chemosensors for pyrophosphate. Acc. Chem. Res. 2009, 42, 23-31. [CrossRef]

22. Zeng, Z.; Torriero, A.A.J.; Bond, A.M.; Spiccia, L. Fluorescent and electrochemical sensing of polyphosphate nucleotides by ferrocene functionalised with two $\mathrm{Zn}(\mathrm{II})(\mathrm{TACN})$ (pyrene) complexes. Chem. Eur. J. 2010, 16, 9154-9163. [CrossRef] [PubMed]

23. Liu, D.J.; Credo, G.M.; Su, X.; Wu, K.; Lim, H.C.; Elibol, O.H.; Bashir, R.; Varma, M. Surface immobilizable chelator for label-free electrical detection of pyrophosphate. Chem. Commun. 2011, 47, 8310-8312. [CrossRef] [PubMed]

24. Terenteva, E.A.; Apyari, V.V.; Dmitrienko, S.G.; Garshev, A.V.; Volkov, P.A.; Zolotov, Y.A. Determination of pyrophosphate and sulfate using polyhexamethylene guanidine hydrochloride-stabilized silver nanoparticles. Talanta 2018, 180, 346-351. [CrossRef]

25. Lin, Y.; Hu, L.; Li, L.; Wang, K.; Ji, Y.; Zou, H. Electrochemical determination of pyrophosphate at nanomolar levels using a gold electrode covered with a cysteine nanofilm and based on competitive coordination of $\mathrm{Cu}$ (II) ion to cysteine and pyrophosphate. Microchim. Acta 2015, 182, 2069-2075. [CrossRef]

26. Baykov, A.A.; Hyytia, T.; Turkina, M.V.; Efimova, I.S.; Kasho, V.N.; Goldman, A.; Cooperman, B.S.; Lahti, R. Functional characterization of Escherichia coli inorganic pyrophosphatase in zwitterionic buffers. Eur. J. Biochem. 1999, 260, 308-317. [CrossRef]

27. Baykov, A.A.; Sergina, N.V.; Evtushenko, O.A.; Dubnova, E.B. Kinetic characterization of Rhodospirillum rubrum $\mathrm{H}^{+}{ }_{-}$ pyrophosphatase in membrane-bound and isolated states. Eur. J. Biochem. 1996, 236, 121-127. [CrossRef]

28. Gordon-Weeks, R.; Korenkov, V.D.; Steele, S.H.; Leigh, R.A. Tris is a competitive inhibitor of $\mathrm{K}^{+}$activation of the vacuolar $\mathrm{H}^{+}$-pumping pyrophosphatase. Plant. Physiol. 1997, 114, 901-905. [CrossRef]

29. Nagul, E.A.; McKelviea, I.D.; Worsfold, P.; Kolev, S.D. The molybdenum blue reaction for the determination of orthophosphate revisited: Opening the black box. Anal. Chim. Acta 2015, 890, 60-82. [CrossRef]

30. Itaya, K.; Ui, M. A new micromethod for the colorimetric determination of inorganic phosphate. Clin. Chim. Acta 1966, 14, 361-366. [CrossRef] 
31. Flodgaard, H.; Fleron, P. Thermodynamic parameters for the hydrolysis of inorganic pyrophosphate at $\mathrm{pH} 7.4$ as a function of $\left[\mathrm{Mg}^{2+}\right],\left[\mathrm{K}^{+}\right]$, and ionic strength determined from equilibrium studies of the reaction. J. Biol. Chem. 1974, 249, 3465-3474. [CrossRef]

32. Nyrén, P.; Lundin, A. Enzymatic method for continuous monitoring of inorganic pyrophosphate synthesis. Anal. Biochem. 1985, 151, 504-509. [CrossRef]

33. Ronaghi, M.; Uhlén, M.; Nyrén, P. A sequencing method based on real-time pyrophosphate. Science 1998, 281, 363-365. [CrossRef]

34. Baykov, A.A.; Fabrichniy, I.P.; Pohjanjoki, P.; Zyryanov, A.B.; Lahti, R. Fluoride effects along the reaction pathway of pyrophosphatase. Evidence for a second enzyme-pyrophosphate intermediate. Biochemistry 2000, 39, 11939-11947. [CrossRef]

35. Belogurov, G.A.; Malinen, A.M.; Turkina, M.V.; Jalonen, U.; Rytkönen, K.; Baykov, A.A.; Lahti, R. Membrane-bound pyrophosphatase of Thermotoga maritima requires sodium for activity. Biochemistry 2005, 44, 4004-4010. [CrossRef]

36. Fabrichniy, I.P.; Kasho, V.N.; Hyytia, T.; Salminen, T.; Halonen, P.; Dudarenkov, V.Y.; Heikinheimo, P.; Chernyak, V.Y.; Goldman, A.; Lahti, R.; et al. Structural and functional consequenses of substitutions at the tyrosine 55-lysine 104 hydrogen bond in Escherichia coli inorganic pyrophosphatase. Biochemistry 1997, 36, 7746-7753. [CrossRef]

37. Springs, B.; Welsh, K.M.; Cooperman, B.S. Thermodynamics, kinetics, and mechanism in yeast inorganic pyrophosphatase catalysis of inorganic pyrophosphate: Inorganic phosphate equilibration. Biochemistry 1981, 20, 6384-6391. [CrossRef]

38. Baykov, A.A.; Shestakov, A.S.; Kasho, V.N.; Vener, A.V.; Ivanov, A.H. Kinetics and thermodynamics of catalysis by the inorganic pyrophosphatase of Escherichia coli in both directions. Eur. J. Biochem. 1990, 194, 879-887. [CrossRef]

39. Smirnova, I.N.; Kasho, V.N.; Volk, S.E.; Ivanov, A.H.; Baykov, A.A. Rates of elementary steps catalyzed by rat liver cytosolic and mitochondrial inorganic pyrophosphatases in both directions. Arch. Biochem. Biophys. 1995, 318, 340-348. [CrossRef] [PubMed]

40. Arakawa, H.; Karasawa, K.; Igarashi, T.; Suzuki, S.; Goto, N.; Maeda, M. Detection of cariogenic bacteria genes by a combination of allele-specific polymerase chain reactions and a novel bioluminescent pyrophosphate assay. Anal. Biochem. 2004, 333, $296-302$. [CrossRef] [PubMed]

41. Baykov, A.A.; Bakuleva, N.P.; Rea, P.A. Steady-state kinetics of substrate hydrolysis by vacuolar $\mathrm{H}^{+}$-pyrophosphatase. A simple three-state model. Eur. J. Biochem. 1993, 217, 755-762. [CrossRef] [PubMed]

42. Smith, R.M.; Alberty, R.A. The apparent stability constants of ionic complexes of various adenosine phosphates with divalent cations. J. Am. Chem. Soc. 1956, 78, 2376-2380. [CrossRef]

43. Childs, C.W. Potentiometric study of equilibriums in aqueous divalent metal orthophosphate solutions. Inorg. Chem. 1970, 9 , 2465-2469. [CrossRef]

44. Smirnova, I.N.; Shestakov, A.S.; Dubnova, E.B.; Baykov, A.A. Spectral and kinetic studies of phosphate and magnesium ion binding to yeast inorganic pyrophosphatase. Eur. J. Biochem. 1989, 182, 451-456. [CrossRef] [PubMed]

45. Daniele, P.G.; De Robertis, A.; De Stefano, C.; Gianguzza, A.; Sammartano, S. Salt effects on the protonation of orthophosphate between 10 and 50 degrees Celsius in aqueous solution. A complex formation model. J. Solut. Chem. 1991, 20, 495-515. [CrossRef]

46. Bisswanger, H. Enzyme Kinetics. Principles and Methods, 2nd ed.; Wiley-VCH Verlag: Weinheim, Germany, 2008 ; pp. 78-85.

47. Cornish-Bowden, A. The use of the direct linear plot for determining initial velocities. Biochem. J. 1975, 149, 305-312. [CrossRef] [PubMed] 